\title{
Cerrahi kliniklerdeki sağlık çalışanlarının aydınlatılmış onam hakkındaki görüş̧leriyle uygulamaları örtüşüyor mu?
}

\author{
Are in surgical clinic health workers' views and practices related to the \\ informed consent consistent with each other?
}

\author{
Gülay Yıldırım*, İlknur Bilgin, Hacer Tokgöz \\ Tıp Tarihi ve Etik Anabilim Dalı (Yrd. Doç. Dr. G. Yıldırım), Cumhuriyet Üniversitesi Tıp \\ Fakültesi, Ebelik Bölümü (Öğr. Gör. İ. Bilgin, Yük. Lis. Öğr. H. Tokgöz), Cumhuriyet \\ Üniversitesi Sağlık Bilimleri Fakültesi, TR-58140 Sivas
}

\begin{abstract}
Özet
Amaç. Sağlık profesyonellerinin aydınlatılmış onama ilişkin görüş ve uygulamalarını değerlendirmek. Yöntem. Tanımlayıcı tipteki araştırmanın örneklemini, Sivas il merkezinde bulunan üç hastanenin cerrahi ünitelerinde çalışan toplam 143 sağlık profesyoneli oluşturdu. Veriler aydınlatılmış onama iliş̧in araştırmacılar tarafindan oluşturulan form ile toplandı. Bu formdan alınabilecek toplam puan 45-225 arasında olup, alınan puanın düşük olması aydınlatılmış onam bilgilerinin doğru ve istendik olduğunu, puanın yüksek olması ise bilgilerinin olumsuz ve istendik olmadığını göstermektedir. Veriler Student t Testi, Kruskall Wallis Testi ve Korelasyon Analizi ile değerlendirildi. Bulgular. Araştırmaya katılan bireylerin yaş ortalaması $32,4 \pm 6,0$ olup, \%63,6'sı kadındı. Calışanların ortalama hizmet süresinin $10,0 \pm 6,5$ yıl olduğu belirlendi. Sağlık profesyonellerin \%47,6'sının onamın doğru uygulandığına kısmen katıldı̆̆ı, \%56,6'sının onamı ispat güvencesi olarak değerlendirdiği, \%57,4'ünün olumsuz iş koşulları ve personel sayısının azlığı nedeniyle çalışılan kurumda onamın istendik düzeyde alınamadığı, \%77,6'sının hastane yönetimi ve yasal zorunluluk nedeniyle alındı ̆̆ı, onam alma sorumluluğu $\% 62,2$ oranında tüm ekibe ait olduğu saptandı. Katılımcıların anket formunun her bir maddesinden aldığı en düşük puan ortalaması 1,60 $\pm 0,66$; en yüksek puan ortalaması ise 3,00 $\pm 1,30$ olup anketten aldıklar toplam puan ortalaması $92,99 \pm 21,75^{\prime}$ ti. Katılımcıların verdikleri aydınlatılmış onamdaki bilginin açık anlaşılır olması gerektiğine yönelik altıncı maddenin puan ortalaması en düşük düzeydeyken hastanın kliniğe ilk geldiğinde verdiği onamın tüm işlemler için geçerli olamayacağına ilişkin 12 . önermenin puan ortalaması en yüksek düzeydeydi. Hekim, hemşire ve ebenin aldığı toplam puan ortalamaları arasında anlamlı fark bulunamadı $(\mathrm{p}>0,05)$. Sonuç. Sağlık çalışanlarının aydınlatılımış onamla ilgili görüşleri olumlu yönde olmasına karşın uygulamaları istendik düzeyde değildir. Katılımcılar, çoğunlukla onamın etik boyutundan çok yasal yönüyle ilgilenmektedirler. Bu bağlamda kurumsal ve eğitim süreci içerisinde aydınlatılmış onamın uygulanmasına ilişkin etkin stratejilerin geliştirilmesine gereksinim vardır.
\end{abstract}

Anahtar sözcükler: Aydınlatılmış onam, sağlık çalışanı, cerrahi klinik

\begin{abstract}
Aim. To evaluate the views and practices of physicians, nurses and midwives working in surgical clinics regarding the informed consent. Methods. The sample of this descriptive study comprises 143 health professionals working in surgical units of three hospitals in the province of Sivas. Data were collected using the questionnaire prepared by the researchers. The possible total score to be obtained from the questionnaire ranges from 45 to 225 . Low scores indicate that their knowledge about the informed consent is correct and sufficient and high scores indicate that their knowledge is negative and insufficient. The data were evaluated with the Student's $t$ test, Kruscall Wallis and Correlation Analysis. Results. The mean age of the participants was $32.4 \pm 6.0$. Of them, $63.6 \%$ were female. Their total length of service was determined as $10.0 \pm 6.5 .47 .6 \%$ partly agreed that informed consent was applied correctly, $56.6 \%$ considered informed consent as the evidence of proving, $57.4 \%$ stated that informed consent could not be obtained satisfactorily due to negative work conditions and the small number of the staff, $77.6 \%$ stated that informed consent was obtained upon the hospital management's demand and due to legal obligation and $62.2 \%$ stated
\end{abstract}


that it was the responsibility of the whole team to obtain informed consent. The lowest and the highest mean scores the participants obtained from the each item of the questionnaire were $1.60 \pm$ 0.66 and $3.00 \pm 1.30$ respectively. Their total mean score was $92.99 \pm 21.75$. While the mean score given by health professionals to the sixth proposition stating that "information in the informed consent must be clear and understandable" was the lowest, the highest mean score was given to the twelfth proposition stating that "the informed consent given by the patient when he/she is admitted to the clinic is not valid for all the procedures". No significant differences were determined between the total mean scores of the physicians, nurses and midwives $(p>0.05)$. Conclusion. Although the health professionals' views regarding informed consent was positive, they did not applied it as required. They were concerned about the legal aspects of informed consent rather than ethical dimension. In this context, it is necessary to develop effective institutional strategies during the education process regarding the implementation of informed consent.

Keywords: Informed consent, health workers, surgical clinics

Geliş tarihi/Received: 13 Ekim 2014; Kabul tarihi/Accepted: 17 Aralık 2014

\author{
*İletişim adresi: \\ Dr. Gülay Yıldırım, Tıp Tarihi ve Etik Anabilim Dalı, Cumhuriyet Üniversitesi Tıp Fakültesi, tr- \\ 58140 Sivas. E-posta: gyildirimg@gmail.com
}

\begin{abstract}
*Bu makale Kasım 2013, İstanbul'da 4. Uluslararası Tıp Etiği ve Tıp Hukuku Kongresinde “Cerrahi kliniklerindeki hekim, hemşire ve ebelerin aydınlatılmış onama ilişkin görüş̧ ve uygulamalarının değerlendirilmesi” başlığıyla sözlü bildiri olarak sunulmuştur.
\end{abstract}

\title{
Giriş
}

Aydınlatılmış onam öğretisi bireyin karar verme esasına dayanır ve sağlık profesyonelibirey ilişkisinin temelini oluşturur. Her bireyin kendi bedenine ne yapılacağını bilme ve belirleme hakkı, ülkelerin yasal düzenlemeleriyle garanti altına alınmış olması sağlık çalışanlarına aydınlatılmış onam elde etme ödevini ortaya çıkarmıştır. Bununla birlikte tıbbi işlem öncesi bireyin aydınlatılmış onamının olmaması ya da uygun bir şekilde alınamaması klinik uygulamalarda önemli etik ve hukuk sorunların ortaya çıkmasına neden olmaktadır [1]. Aydınlatılmış onam, hastanın karar vermeye yeterli ve gönüllü olmasını, bilginin açıklanmasını ve anlaşı1ır olmasını zorunlu kılmaktadır [2, 3]. Bununla birlikte bilgilendirmenin hasta tarafindan anlaşıldığından da sağlık profesyonelleri emin olmalidir.

Aydınlatılmış onam alma yükümlülügüu, tıbbi işlemi yapan sağlı çalışanının sorumluluğudur. Dolayısıyla epizyotomi, normal doğum, vaginal muayene, sonda takma, sağlık eğitimi verme ve muayene yapma gibi uygulamalar ebelerin ve hemşirelerin bağımsız rollerini yerine getirirken onam alma yükümlülügünü gündeme getirmektedir. Türkiye Biyoetik Derneği birincil olarak hekimin ve hasta bakımından sorumlu sağlık çalışanlarının onam almasını önermektedir [4].

Aydınlatılmış onamla ilgili çalışmalar daha çok hekim üzerine odaklanırken ebe ve hemşirelerin konuyla ilgili görüş ve bilgilerini araştıran çalışmalara rastlanılamamıştır. Askeri hastanede hastalar üzerinde yapılan bir çalışmada tanı veya tedaviyle ilgili kararlara katılmaları konusunda sağlanan olanaktan memnun olma düzeylerinin \%48 olduğu saptanmıştır [5]. Aynı çalışmada sağlık çalışanlarının, tanı ve tedavi kararlarında hasta katılımına olanak sağlama durumlarının doktorlarda $\% 38$, hemşirelerde $\% 40,8$ olduğunun belirlenmesi aydınlatılmış onamın yeterli düzeyde uygulanamadığını düşündürebilir. Yapılan diğer çalışmalar da, çoğu hastanın kendisine aktarılan bilgileri anlamadan onay verdiğini göstermiştir [6]. Saruç'un [7], Ankara'daki kadın hastalıkları ve doğumevi hastanelerinde kadın hastaların hasta hakları konusunda bilgi düzeylerini ölçmeye yönelik yaptığı çalışmada en az bilinen hasta hakkının "hastaların kendi rızası olmadan tıbbi müdahaleye tabi tutulmama hakkı" olduğu belirlenmiştir. Bu durum 
hastaların hasta haklarına özgü hastane uygulamalarının yapılamadığı olasılığını akla getirebilmektedir. Aydınlatılmış onam uygulamalarının istendik düzeyde uygulanabilmesi için öncelikle sağlik profesyonellerinin konuyla ilgili etik ve yasal bilgilerinin yeterli olması, konuya yaklaşımlarında duyarlı olmaları önem taşımaktadır. Bu bağlamda çalışmanın amacı sağlık profesyonellerinin uyguladıkları bilgilendirme ve onam alma uygulamalarında aydınlatılmış onama ilişkin görüş ve uygulamalarını değerlendirmektir.

\section{Gereç ve yöntem}

Tanımlayıcı tipteki bu araştırmanın evrenini Sivas il merkezinde yer alan üç hastanede çalışan 199 doktor, 82 ebe ve 318 hemşire olmak üzere toplam 599 birey oluşturmaktadır. Evreni temsil etmesi amaciyla kullanılan formül yardımıyla $[\mathrm{n}=\mathrm{Nt} 2 \mathrm{pq} /(\mathrm{N}-1) \mathrm{d} 2+\mathrm{t} 2 \mathrm{pq}$; $\infty=0,05 ; \mathrm{d}=0,03 \mathrm{p}=0,05]$ doktorlardan 58 'i, ebelerden 24'ü ve hemşirelerden 93'ü çalışmaya alınmıştır $(n=175)$. Her bir hastaneden örnekleme alınacak doktor, ebe ve hemşire sayıları saptanırken tabakalı örnekleme, anket uygulanacak sağlık çalışanları belirlenirken ise basit rastgele örnekleme yöntemi kullanılmıştır. Toplanan anketlerden 32'si eksik doldurulması nedeniyle değerlendirme dışı bırakılmıştır (64 hekim, 19 ebe ve 60 hemşire toplam 143 sağlık çalışanı). Araştırmanın verileri 2 Haziran-2 Ağustos 2013 tarihleri arasında çalışanların kendi ortamlarında toplanmıştır.

\section{Veri toplama araçları}

Araştırmada veriler iki ayrı form ile elde edilmiştir. Sosyo-demografik soru formu; bu formda genel sosyo-demografik özellikler, mesleki bilgiler ve onama ilişkin toplam 16 soru yer almıştır.

Hekim, hemşire ve ebelerin aydınlatılmış onama ilişkin görüşleri formu; aydınlatılmış onama ilişkin araştırmacılar tarafından literatür taranarak oluşturulan 45 önermeli ve 5 seçenekli (tamamen katılıyorum, katılıyorum, kararsızım, katılmıyorum, hiç katılmıyorum) form kullanılmıştır [2, 3, 8-10]. Örneklem grubundan farklı bir grupta ( $\mathrm{n}=$ 30) formun ön uygulaması yapılarak anlaşılmayan sorular yeniden düzenlenmiştir. $\mathrm{Bu}$ formdan alınabilecek toplam puan 45-225 arasında olup puanlama ölçütleri 45-80 puan aras1 "tamamen katıldıkları", 81-116 puan aras1 "katıldıkları", 117-152 puan aras1 "kararsız" oldukları, 153-188 puan arası "katılmadıkları", 189-225 puan arası "hiç katılmadıkları" şeklinde tanımlanmıştır. Alınan puanın düşük olması aydınlatılmış onam uygulamalarının doğru ve istendik olduğunu, puanın yüksek olması ise uygulamaların istendik düzeyde olmadığ 1 ve yanlış olduğunu göstermektedir. Soru formunun Cronbach alfa katsayısı 0,944 'tür.

\section{Verilerin değerlendirilmesi}

Veriler SPSS 14 programında değerlendirilmiştir. Verilerin analizinde; frekans dağılımı, sosyo-demografik özelliklerle puan ortalamalarının karşılaştırılmasında t testi varyans analizi ve Kruskall Wallis varyans analizi, çalışanların hizmet süreleriyle puan ortalamalarının karşılaştırılmasında Korelasyon Analizi, hekim, hemşire ve ebelerin aydınlatılmış onam ile ilgili görüş puanlarının karşılaştırılmasında varyans analizi, farkı doğuran grubun tespitinde Tukey testi uyguland.

\section{Araştırma etiği}

Araştırmanın yapılacağı kurumlardan yazılı izin alınmıştır. Katılımcılara formların eksiksiz doldurulması için araştırma konusu ve amacı hakkında bilgi verilip ardından aydınlatılmış onam formunun okunması sağlanmıştır. Katılımcılara çalışmaya katılıp katılmama kararının kendilerine ait olduğu, anketlerin üzerine isim yazmamaları, elde edilen bilgilerin çalışma dışında kullanılmayacağı, kişisel bilgilerinin gizliliğinin korunacağı ifade edildikten sonra araştırmaya katılmayı kabul edenlere anketler verilerek yaklaşık 15-20 dakika sonra toplanmıştır. 


\section{Bulgular}

\section{Örneklemin özellikleri}

Araştırmaya katılan bireylerin yaş ortalaması 32,4 $\pm 6,0$ olup, \%63,6'sı kadın, \%67,8'si evli, ebe ve hemşirelerin \%34,3'ü önlisans mezunudur. Çalışanların toplam hizmet süresi ortalamasının 10,0 \pm 6,5 olduğu, \%51,7'sinin 0-10 yıl arasında çalıştığı ve \%72.7'sinin öğrenim gördüğü yıllarda aydınlatılmış onamla ilgili ders almadığı belirlendi (Tablo 1). Sağlık profesyonellerinin \%47,6'sının onamın doğru uygulandığına kısmen katıldığı, $\% 33,6$ 'sının onamın istendik düzeyde uygulanmaması nedenini personel sayısının yetersizliğine, $\% 23,8$ 'inin olumsuz iş koşullarına bağladığ 1 , \%77,6'sının hastane yönetimi ve hukuki gerekçe nedeniyle onam aldığ 1 saptandı (Tablo 2). Bununla birlikte katılımcıların \%56,6'sının (81 kişi) onamı ispat güvencesi olarak değerlendirdiği, $\% 62,2$ 'sinin (89 kişi) ise onam alma sorumluluğunun tüm ekibe ait olduğu görüşünü paylaştığı saptandı.

Tablo 1. Çalışmaya alınanların bazı sosyo-demografik özelliklerine göre dağılımı.

\begin{tabular}{ll}
\hline Özellik & Sayı (\%) (n=143) \\
\hline Yaş dağılımı & $\mathbf{3 2 , 4} \pm \mathbf{6 , 0}(\mathbf{1 8 m i n}-\mathbf{5 8 m a x})$ \\
\hline Cinsiyet & $91(63,6)$ \\
Kadın & $52(36,4)$ \\
Erkek & \\
\hline Medeni durum & $97(67,8)$ \\
Evli & $45(31,5)$ \\
Bekar & \\
\hline Eğitim & $49(34,3)$ \\
Ön lisans & $30(21,0)$ \\
Lisans & $64(44,8)$ \\
Uzmanlık & \\
\hline Meslek & $64(44,8)$ \\
Hekim & $60(42,0)$ \\
Hemşire & $19(13,3)$ \\
Ebe & \\
\hline Hizmet süresi & $74(51,7)$ \\
0-10 yıl & $55(38,5)$ \\
11-20 & $14(9,8)$ \\
21-30 & $39(27,3)$ \\
\hline Ders alma durumu & $104(72,7)$ \\
Evet & \\
Hayır & \\
\hline &
\end{tabular}

Tablo 2. Aydınlatılmış onamla ilgili uygulama verilerinin dağılımı.

\begin{tabular}{ll}
\hline Veriler & Sayı (\%) (n=143) \\
\hline Doğru uygulanma durumu & \\
Evet & $54(37,8)$ \\
Hayır & $21(14,7)$ \\
Kısmen & $68(47,6)$ \\
\hline Doğru uygulayamama nedeni & \\
Personel sayısı yetersizliği & $48(33,6)$ \\
Olumsuz iş koşulu & $34(23,8)$ \\
Personelin özensizliği & $25(17,5)$ \\
Sağlık çalışanın yetersiz sorumluluğu & $19(13,3)$ \\
Fiziki ortam yetersizliği & $8(5,6)$ \\
Hastanın kendi yetersiz sorumluluğu & $5(3,5)$ \\
Diğer & $4(2,8)$ \\
\hline Aydınlatılmış onamı uygulama nedeni & \\
Hukuki gerekçe & $111(77,6)$ \\
İnsan olma değeri & $32(22,4)$ \\
\hline
\end{tabular}




\section{Aydınlatılmış onama ilişsin görüşler}

Katılımcıların görüşleriyle ilgili soru formunu oluşturan her bir önermeden aldığı en düşük puan ortalaması 1,60 $\pm 0,66$, en yüksek puan ortalaması ise 3,00 $\pm 1,30$ idi. Sağlık profesyonellerinin aydınlatılmış onamdaki bilginin açık anlaşılır olması gerektiğine yönelik altınc1 önermeye verdikleri puan ortalaması en düşük düzeydeyken hastanın kliniğe ilk geldiğinde verdiği onamın tüm işlemler için geçerli olamayacağına ilişkin 12 . önermenin puan ortalaması en yüksek düzeydeydi. Katılımcıların anketin tüm önermelerinden aldıkları toplam puan ortalaması ise $92,99 \pm 21,75$ olup \%65,7'sinin puan aralığ $81-116$ 'dır. Alınan puan ortalamasıyla sosyo-demografik özellik ve onamla ilgili veriler arasında anlamlı fark bulunamadı $(\mathrm{p}>0,05)$. Ancak puan ortalamasıyla çalışanların hizmet süreleri arasında negatif yönde zayıf düzeyde anlamlı ilişki bulundu $(r=-0,165 ; \mathrm{p}=$ 0,049 ).

Katılımcıların her bir önerme maddelerinden alınan puan ortalamaları değerlendirildiğinde hastanın kliniğe ilk geldiğinde verdiği onamım tüm işlemler için geçerli olamayacağını ifade eden 12. önermeye sağlık çalışanlarının \%34,3'ü katılmadığını ifade etmiş̧tir. Genel onamın yasal geçerliliğinin olmadığını belirten 14 önermeye \%32,2'si katılırken \%28,0'1 kararsız kalmıştır. Hastanın kesinlikle bilgilendirilmemek istemiyorsa bilgilendirilmemesi gerektiğine ilişkin 27. önermeye $\% 34,3$ 'ü katılırken \%22,4'ü kararsız olduğunu belirtmiş̦tir. Birey mevcut sağlık sorunuyla ilgili durumunu önceden bilse bile bilgilendirme yapılmasına ilişkin 19. önermeye katılımcıların \%25,9'u katılırken \%22,4'ü kararsız olduğunu bildirmiştir (Tablo 3). Hekim, hemşire ve ebelerin aydınlatılmış onamla ilgili görüş puanları karşılaştırıldığında, eksik bilgilendirmeyle alınan rızanın geçersiz olduğu ile ilgili 7. önerme, bilgilendirmenin hastayı kötü yönde etkilemesi durumunda aile yakınlarına bilgilendirme yapılmasını öngören 17. önerme ve her türlü tıbbi girişim hastanın vücut bütünlügünü zedeleyen bir işlem olduğuna ilişkin 26. önermenin puan ortalamaları hemşire ve ebelerde hekimlere göre istatistiki açıdan anlamlı ölçüde daha düşük bulundu $(\mathrm{p}<0,05)$ (Tablo 4).

Tablo 3. Aydınlatılmış onamla ilgili bazı önermelerin puan dağılımı.

\begin{tabular}{|c|c|c|c|c|c|c|}
\hline \multirow[t]{3}{*}{ Önermeler } & $\begin{array}{l}\text { Tamamen } \\
\text { katılıvorum }\end{array}$ & Katılıyorum & Kararsızım & Katılmıyorum & $\begin{array}{l}\text { Hiç } \\
\text { katılmıvorum }\end{array}$ & Toplam \\
\hline & $\mathrm{N}(\%)$ & $\mathrm{N}(\%)$ & $\mathrm{N}(\%)$ & $\mathrm{N}(\%)$ & $\mathrm{N}(\%)$ & $\mathrm{N}(\%)$ \\
\hline & 45-80 puan & $81-116$ puan & $117-152$ puan & $153-188$ puan & $189-225$ puan & $143(100)$ \\
\hline $\begin{array}{l}\text { Birey/hasta kliniğe geldiğinde } \\
\text { bir kez onam verdiğinde } \\
\text { hastanede yapılacak tüm tıbbi } \\
\text { girişimlere onam vermiş gibi } \\
\text { kabul edilmemelidir. }\end{array}$ & $19(13,3)$ & $24(16,8)$ & $28(19,6)$ & $49(34,3)$ & $23(16,1)$ & \\
\hline $\begin{array}{l}\text { Tüm tıbbi girişimler için } \\
\text { hastanede hasta kabul sırasında } \\
\text { alınmış genel aydınlatılmış } \\
\text { onam formları yasal açıdan } \\
\text { geçerli değildir. }\end{array}$ & $26(18,2)$ & $46(32,2)$ & $40(28,0)$ & $21(14,7)$ & $10(7,0)$ & $143(100)$ \\
\hline $\begin{array}{l}\text { Birey/hasta kesin olarak } \\
\text { belirttiği takdirde, } \\
\text { "bilgilendirilmeme hakkına", } \\
\text { sahiptir. }\end{array}$ & $24(16,8)$ & $49(34,3)$ & $32(22,4)$ & $20(14,0)$ & $18(12,6)$ & $143(100)$ \\
\hline $\begin{array}{l}\text { Birey/hasta mevcut sağlık } \\
\text { sorunuyla ilgili durumunu } \\
\text { önceden bilse bile bilgilendirme } \\
\text { yapılmalıdır. }\end{array}$ & $20(14,0)$ & $37(25,9)$ & $32(22,4)$ & $31(21,7)$ & $23(16,1)$ & $143(100)$ \\
\hline
\end{tabular}

Tablo 4. Sağlık çalışanlarının aydınlatılmış onamla ilgili bazı önermelerdeki puan ortalamalarının karşılaştırılması.

\begin{tabular}{lllll}
\hline Önermeler & Hekim & Ebe & Hemşire & Test \\
\cline { 2 - 3 } & $\mathbf{X} \pm \mathbf{S S}$ & $\mathbf{X} \pm \mathbf{S S}$ & $\mathbf{X} \pm \mathbf{S S}$ & \\
\hline $\begin{array}{l}\text { Bireye/hastaya içerikte eksik aydınlatılmış onam uygulanması } \\
\text { alınan onamı geçersiz kılacaktır. }\end{array}$ & $2,54 \pm 1,05$ & $1,84 \pm 0,83$ & $2,15 \pm 0,93$ & $\mathrm{P}=0,010 ; \mathrm{F}=4,809$ \\
\hline $\begin{array}{l}\text { Bilgilendirmenin bireyi/hastayı kötü yönde etkileyeceği } \\
\text { düşünülüyorsa, bilgilendirme yapılmayabilir. Bu durumda } \\
\text { bilgilendirme birey/hasta yakınlarına yapılarak karar, hekim ve } \\
\text { birey/hasta yakınlarıla birlikte alınır. }\end{array}$ & $2,65 \pm 1,21$ & $2,31 \pm 1,00$ & $2,13 \pm 0,92$ & $\mathrm{P}=0,027 ; \mathrm{F}=3,725$ \\
\hline $\begin{array}{l}\text { Hekimin hastalarına yaptığı her türlü tıbbi girişim hastasının } \\
\text { vücut bütünlüğüne yönelik, vücut dokunulmazlığını zedeleyen } \\
\text { bir işlemdir. }\end{array}$ & $2,92 \pm 1,28$ & $2,05 \pm 1,17$ & $2,36 \pm 1,02$ & $\mathrm{P}=0,004 ; \mathrm{F}=5,662$ \\
\hline
\end{tabular}




\section{Tartışma}

Sağlık profesyonellerinin bilgilendirme ve onam alma pratiklerinde aydınlatılmış onama ilişkin görüş ve uygulamalarını değerlendirmek amacıyla yapılmış bu araştırmada, sağlık çalışanlarının aydınlatılmış onamla ilgili puanının ortalamanın üzerinde olması aydınlatılmış onama ilişkin görüşlerinin doğru ve istendik yönde olduğunu yansıtmaktadır. Aydınlatılmış onamın uygulamaya yansıtılması yönüyle değerlendirildiğinde ise çoğunlukla onamın etik boyutundan çok yasal yaptırım yönüyle ilgilenildiği, zorunluluk nedeniyle aydınlatılmış onamın alındığ düzeyde yapılamadığı ifade edilebilir. Katılımcılar aydınlatılış onamın uygulamaya yeterince yansıtılamaması nedenlerini sağlık çalışanı sayısının azlığına ve olumsuz iş koşullarına bağlamaktadırlar. Turla ve ark. [11]'nın yaptığ 1 çalışmada hekimlerin $\% 84,3$ 'ü bilgilendirme ve aydınlatma amaciyla hastalarına 10 dakikadan daha az zaman ayırdığını, bunun nedenleri arasında da personel sayısının yetersiz olduğu belirtilmiştir. KKTC'deki yataklı tedavi kurumlarında çalışan hemşire ve hekimlerin hasta haklarına duyarlılığının belirlenmesi amacıyla yapılan bir çalışmada, verilerin toplanmasında kullandıkları "hasta haklarına inanç formunun" "bilgilendirme ve onay" alt grubu sorularından alınan puan ortalamalarının düşük olduğu belirlenmiştir [12]. Cerrahi hastaları üzerinde yapılan çalışmada da hastaların \%89,9'u hekim tarafından kendilerine açıklama yapıldığını ancak hastaların \%74,2'sinin kendisine yapılan açıklamanın tatmin edici bulmadıklarını ifade etmiştir [13]. Ersoy [14]'un yaptığı bir çalışmada hastaların tamamına yakını hastalıkları ve tedavileri konusunda bilgi edinmek isterken, cerrahların büyük çoğunluğunun hastaların kendileri ile ilgili bilgi istemediklerine inandıkları belirtilmiştir. Yaşar Teke ve ark. [15]'nın çalışmasında hekimlerin \%39,4 oranında tıbbi işlem öncesi aydınlatılmış onam almadıkları, Turla ve ark. [11]'nın araştırmasında hekimlerin \%64,7'si tüm mesleki uygulama öncesinde onam aldıkları belirlenmiştir. Aydın Er ve ark. [16] ortopedi hastaları üzerinde yaptıkları bir çalışmada aydınlatılmış onamın etik kural ve yönetmeliğe göre istendik düzeyde alınmadığı sonucuna ulaşmışlardır. Yapılan arastırmalarda aydınlatılmış onamın uygulanışının istendik düzeyde olmadığ 1 ve sağlık çalışanlarının paternalist yaklaşım gösterdikleri belirlenmiştir $[11,13,17]$. Poliklinik hastalarının hasta hakları hakkındaki görüşlerinin belirlendiği çalışmada, hastaların en çok bildikleri arasında ilk ikinci sırada rızasının alınması gerektiği bulunurken en bilmediklerinin arasında ikinci sırada bilgilendirilme hakkı yer almaktadır [18]. Bu durum hastalar kendilerine ne uygulanıyorsa onu bildikleri ön kabulüne göre uygulamalarda bilgilendirme yapılmadan rıza alındığının göstergesi olabilir.

Araştırmamızda katılımcıların onama ilişkin görüşlerinin doğru ve istendik yönde oldukları görülmektedir. Bu sonucu destekler nitelikte Aktan ve Şehiraltı'nın [19] Kocaeli'nde bir fuarda diş hekimleri üzerinde yaptıkları çalışmada, aydınlatılmış onam konusunda diş hekimlerinin tutumlarının ve uygulamalarının genel olarak pozitif yönde oldukları belirlenmiştir. Yine Aydın ve ark. [20] tarafından Hacettepe Üniversitesi Tıp Fakültesi Hastanesi hekimlerine uygulanan bir çalışmada tıbbi tedavi ve müdahale riskleri hastaya açıklanmalıdır" ifadesine hekimlerin \%99,4'nün, "tıbbi tedavi hakkında karar verebilmesi için hastaya zaman tanınmalıdır" ifadesine \%90,5'inin, "tıbbi karar, hekim ve hasta tarafından ortak alınmalıdır" ifadesine \%89,3'ünün katılmış olmaları onama yönelik yaklaşımların olumlu yönde olduğunu gösterebilir. Bostan [21], sağlık çalışanlarının tıbbi hizmetlerde hasta haklarına yönelik tutumları içinde en yüksek ikinci puan ortalamasının "işlem öncesi hastadan rıza alınmalıdır" ifadesi olduğunu saptamıştır. Terminal dönem hastalarının etik ve hasta haklarıyla ilgili öğrenci hemşireler üzerinde yapılan bir araştırmada, aydınlatılmış onamla ilgili haklara katılma sıklıklarının \%76,0-98,7 arasında değiştiği görülmüştür [22]. Bulgulara göre zayıf olmakla birlikte katılımcıların hizmet süresi arttıkça onamla ilgili puan ortalamalarının istendik düzeyde olduğu saptandı. Aydın Erden ve ark. [23]'nın yaptığı bir çalışmada özellikle yeni başlayan asistanların, sık yapılan birçok cerrahi işlem için onam almada bilgilerinin yetersiz olduğu bildirilmiştir. 
Sağlık profesyonellerinin en fazla savundukları önerme aydınlatılmış onamın uygulanışındaki bilginin açık anlaşılır olması gerektiğidir. En az savundukları önerme maddesi ise hastanın kliniğe ilk geldiğinde verdiği onamın tüm işlemler için geçerli olamayacağıdır. [24] Etik ve yasal açıdan bilgilerin açık olması istendiktir. Ancak tüm işlemler için bir defa onam almak anlamına gelen genel onam hukuk karşısında geçerli değildir. Katılımcılar genel onam alınmasını kabul ederken yarıya yakını genel onamın yasal geçerliliğinin olmadığ çalışanlarının çoğunlukla genel onamın yasal açıdan kabul edilmediğinin farkında olduklarını, yasal süreci dikkate almadıklarını veya önemsemediklerini düşündürebilir. Turla ve ark.[11]'nın bir üniversite hastanesi hekimleri üzerinde yaptıkları çalışmada, hekimler yapacakları tıbbi işlem öncesi \%35,8 oranında sözel izin aldıklarını, \%29,4 oranında kurumlarınca düzenlenmiş matbu belge kullandıklarını ifade etmişlerdir. Aydınlatılmış onam uygulamasında yapılan bilgilendirmeyi hastanın anlaması önemlidir. Bu sebeple matbu aydınlatmadan kaçınılmalı ve aydınlatma bu anlamda kişisel olmalıdır.

Birey/hasta mevcut sağlik sorunuyla ilgili durumunu önceden bilse bile bilgilendirmenin yapılmaması gerektiğine sağlık çalışanları büyük çoğunluk katılsa da, katılmayanların ikinci sırada olması bu konuda net olamadıklarının göstergesi olabilir.

Hemşire ve ebelerin eksik bilgilendirmeyle alınan rızanın geçersiz olduğu, bilgilendirmenin hastayı kötü yönde etkilemesi durumunda aile yakınlarına bilgilendirme yapılması gerektiği ve her türlü tıbbi girişim hastanın vücut bütünlüğünü zedeleyen bir işlem olduğuna ilişkin önermelere hekimlere göre daha düşük yani istendik puan verdikleri belirlenmiştir. Bunun nedeni onların bakım ve hasta savunuculuğu rollerine, hekime göre hastayla daha fazla zaman geçirmelerinden dolayı hastayı yakından tanımalarına ve sorunlarına birincil elden tanık olmalarına bağlanabilir.

Sonuç olarak; teorik anlamda sağlık çalışanları aydınlatılmış onam alma yaklaşımlarının çoğunlukla doğru olmasına karşın uygulamalarının istendik düzeyde olmadığı ifade edilebilir. Çoğunlukla onamın sağlık çalışanları tarafından etik boyutundan çok yasal yönüyle ilgilenildiği ifade edilebilir. Bu bağlamda aydınlatılmış onamın uygulanmasıyla ilgili sorunların tanımlanması ve çözümüne yönelik kurumsal stratejilerin oluşturulmasına ve kurum politikalarının geliştirilmesine gereksinim vardır. Bu çalışmanın yürütüldüğü kurumlarda çalışanlara yönelik genel onam alma ve bilgilendirme hakkı konularında hizmet içi programlarının planlanması yararlı olacaktır. Sağlık çalışanlarının bu uygulamayı davranış modeli haline getirmelerinin sağlanması için eğitim çalışmaları ve denetimin arttırılması önerilebilir.

\section{Kaynaklar}

1. Dhar H, Dhar D. Informed consent in clinical practice and literature overview. Arch Gynecol Obstet 2012; 286: 649-51.

2. Ersoy N, Erdemir AD, Öncel Ö, Aksoy S. Aydınlatılmıs Onam; Çagdas Tıp Etiği. Nobel Tip kitapevi yayınc1. 2003; 204-34.

3. Christopoulos P, Falagas ME, Gourzis P, Trompoukis C. Aspects of Informed Consent in Medical Practice in the Eastern Mediterranean Region During the 17th and 18th Centuries. World J Surg 2007; 31: 1587-91.

4. Türkiye Biyoetik Derneği, Aydınlatılmış onam almak üzerine öneriler: http://irisinteraktif.com/Biyoetik/files/raporlar/AORapor.pdf Erişim tarihi: 9 Ekim 2014.

5. Ataç A, Azal Ö, Uçar M, Açıkel CH, Göçgeldi E. TSK sağlık kurumlarından yararlanan personelin hasta hakları ve sağl1k personeli-hasta ilişkisi konusundaki memnuniyetlerinin intranet üzerinden araştırılması. Gülhane Tıp Dergisi 2003; 45: 309-15.

6. Aydınlatılmış onam hazırlama ve kullanma rehberi Adana: Çukurova Üniversitesi Tip Fakültesi Hastanesi 2005.

7. Saruç, S. Kadın hastalıkları ve doğumevi eğitim ve araştırma hastanelerinde yatan hastaların hasta hakları bilgi düzeyinin belirlenmesi: Ankara örneği. Ankara: 
Hacettepe Üniversitesi, Sosyal Bilimler Enstitüsü, Sosyal Hizmetler Anabilim Dalı, Yüksek Lisans Tezi 2007.

8. Arda B, Civaner M, Kavas MV, Özgönül L. Aydınlatılmış Onam. Ed. Carmi A. UNESCO, Ankara 2004: 1-59.

9. Kara M, Hızal A, Hızal SA. Aydınlatılmış Onam. İzmir Tabip Odası, 2009: 1-90.

10. Türk Tabipleri Birliği. Etik bildirgeler. TTB yayınları, Ankara 2010: 14.

11. Turla A, Karaarslan B, Dabak Ş, Ondokuz Mayıs Üniversitesi T`p Fakültesi'nde Görev Yapan Hekimlerin "Aydınlatılmışl Onam" Konusundaki Bilgi ve Tutumlar1. O.M.Ü. Tıp Dergisi 2004; 21: 57-63.

12. Savaşkan F, Acaroğlu R. KKTC'deki yataklı tedavi kurumlarında çalışan hemşire ve hekimlerin hasta haklarına duyarlılığının belirlenmesi. İstanbul: İstanbul Üniversitesi Sağlık Bilimleri Enstitüsü, Hemşirelik Esasları Anabilim Dalı, Yüksek Lisans Tezi 2006.

13. Turla A, Karaarslan B, Kocakaya M, Pekşen Y. Hastalara yeterince aydınlatma yapılıp-yapılmadığı ve onam alınması durumunun saptanması. Turkiye Klinikleri J Foren Med 2005; 2: 33-8.

14. Ersoy N. Klinik etiğin önemli sorunu: Aydınlatılmış onam. Turkiye Klinikleri Tibbi Etik 1994; 2: 131-6.

15. Yaşar Teke H, Alkurt Alkan H. Başbulut AZ, Cantürk G. Tıbbi Uygulama Hataları ile ilgili Kanuni düzenlemelere hekimlerin bakışı ve bilgilenme düzeyi: Anket çalışması. Turkiye Klinikleri J Foren Med 2007; 4: 61-7.

16. Aydın Er R, Özcan M, Akpınar A, Ersoy N. Ortopedide aydınlatılmış onama ait etik sorunlar: Kocaeli'den Bir Örnek. Türkiye Klinikleri J Med Sci 2011; 31: 455-63.

17. Kişioğlu AN, Tüfekçi F, Uskun E, Bakır B. Bir Devlet hastanesinde yatan hastaların bilgilendirilme ve aydınlatılmış onam durumunun değerlendirilmesi. Turkiye Klinikleri J Med Ethics 2001; 9: 98-101.

18. Ünsal A, Bulucu G D, Kura E, Ercan Y. Poliklinik hizmeti alan hastaların hasta haklarına ilişkin bilgi düzeyleri Fırat Saglık Hizmetleri Dergisi 2011; 6: 27-40.

19. Aktan N, Şehiralttı M, Diş hekimlerinin aydınlatılmış onam hakkındaki bilgi tutum ve deneyimlerinin incelenmesi. Kccaeli üniversitesi Sağlık Bilimleri Enstitüsü, Tıp Tarihi ve Etik Anabilim Dalı, Yüksek Lisans Tezi 2005.

20. Aydın E, Sayek İ, Ergun Karaağaoğlu E, Örnek Büken N. Hacettepe Üniversitesi Tıp Fakültesi klinisyen hekimlerinin etik bilgi ve farkındalıkları. Hacettepe Tip Dergisi 2006; 37: 98-115.

21. Bostan S. Sağlık çalışanlarının hasta haklarına yönelik tutumlarının araştırılması: Farabi Hastanesi Örneği. Hacettepe Sağlık İdaresi Dergisi 2007; 10: 1-18.

22. Gürkan A, Babacan Gümüş A, Dodak H. Öğrenci hemşirelerin terminal dönem hasta sorunları hakkındaki görüşleri: Hemşirelik girişimleri, hasta hakları ve etik sorunlar kapsamında bir inceleme. Maltepe Üniversitesi Hemşirelik Bilim ve Sanatı Dergisi 2011: 4: 2-12.

23. Aydın Erden İ, Pamuk AG, Akıncı SB, Uzun Ş, Önal Ö, Aypar Ü. Anestezi asistanlarının bilgilendirilmiş onam alırken sık karşılaştıkları sorular hakkında bilgilerinin değerlendirilmesi. Türk Anest Rean Der Dergisi 2008; 36: 300-3.

24. Kara M, Hızal A, Hızal Arslan S. Aydınlatılmış onam. İzmir Tabip Odası 2009; 7-90. 